E3S Web of Conferences 1, 37007 (2013)

DOI: $10.1051 / \mathrm{e} 3$ sconf/20130137007

(C) Owned by the authors, published by EDP Sciences, 2013

\title{
Assessment of metals by instrumental neutron activation analysis in six fish species consumed in the city of São Paulo
}

\author{
M. B. Nisti ${ }^{1}$, C. H. R. Saueia ${ }^{1,2}$, B. P. Mazzilli ${ }^{1}$ and N. F. A. Meneses ${ }^{2}$ \\ ${ }^{1}$ Instituto de Pesquisas Energéticas e Nucleares, Av. Prof. Lineu Prestes, 2242 - Cidade Universitária, CEP: 05508-000, \\ São Paulo-SP, BRASIL.mbnisti@ipen.br, chsaueia@ipen.br, mazzilli@ipen.br \\ ${ }^{2}$ Universidade Nove de Julho, Av. Dr. Adolpho Pinto, 109 Barra Funda, Brazil nameneses@ipen.br
}

\begin{abstract}
The objective of this work is to quantify the concentration of the metals $\mathrm{As}, \mathrm{Co}, \mathrm{Cs}, \mathrm{Fe}, \mathrm{K}, \mathrm{Na}, \mathrm{Rb}$, $\mathrm{Sb}, \mathrm{Sc}, \mathrm{Sm}, \mathrm{Th}, \mathrm{U}$ and $\mathrm{Zn}$ in the muscles of six fish species (anchovy, brycon, catfish, hake, pacu and sardine). Metals characterization was performed by instrumental neutron activation analysis (INAA). The elements determination was made by irradiation of approximately $150 \mathrm{mg}$ of each sample (dry weight), during 16 hours at a neutron flux of $10^{12} \mathrm{n} . \mathrm{cm}^{-2} \cdot \mathrm{s}^{-1}$ in the nuclear research reactor IEA-R1 of Instituto de Pesquisas Energéticas e Nucleares (IPEN). Most of the results for the metals concentration is low, exception for As and $\mathrm{Zn}$ in seawater fish and for $\mathrm{Rb}$ in river fish. The results obtained in this study can be used to ensure the quality of the fish consumed in the city of São Paulo.
\end{abstract}

Key words: metals, fish contamination, instrumental neutron activation analysis.

\section{Introduction}

Fish is a food of excellent nutritional quality; therefore, its consumption has significantly increased in Brazil in the last years (Fabiano et al., 2011). It also represents an important part of the alimentary diet. The metals contamination in the ecosystem is significant and can be harmful, since the metals present a high degree of bioaccumulation (Governo do Estado de São Paulo, 1974). The absorption of metals in the food chain can cause severe health damage to the final consumers (Nascimento et al., 2009).

Therefore, it is important to determine the amount of metals in fishes, for the evaluation of the potential risk for human health. The metals concentration in fishes was determined by instrumental neutron activation analysis (INAA). INAA is based on the reaction between neutrons and a target nucleus. The neutron is captured by the nucleus and produces an excited nucleus, which decays according to its half-life time and emits gamma-radiation.

\section{Materials and Methods}

The fish muscle samples were purchased in a supermarket in the city of São Paulo. The species of fish analyzed and scientific name are anchovy (Pomatomus saltatrix), brycon (Brycon amazonicus), catfish (Bagre marinus), hake (Merluccius merluccius), pacu (Piaractus mesopotamicus) and sardine (Sardina pilchardus). The fishes of seawater are anchovy, catfish, hake and sardine; the fishes of rivers are brycon and pacu. The humid samples were weighed and dried at $50^{\circ} \mathrm{C}$ for a period of 24 hour. Each fish sample was analyzed in triplicate. The determination of the metals As, Co, Cs, Fe, K, Na, Rb, $\mathrm{Sb}, \mathrm{Sc}, \mathrm{Sm}, \mathrm{Th}, \mathrm{U}$ and $\mathrm{Zn}$ was carried out by irradiation of approximately $150 \mathrm{mg}$ of each sample, during 16 hours at a neutron flux of $10^{12} \mathrm{n} . \mathrm{cm}^{-2} \mathrm{~s}^{-1}$, at the nuclear research reactor IEA-R1 of Instituto de Pesquisas Energéticas e Nucleares (IPEN).

The first count was made after 7 days of decay and the second count was made after 15 days of decay. The induced radioactivity was measured by gamma-spectrometry with a hyper-pure germanium detector, EGPC 25 coaxial, with $25 \%$ relative efficiency and resolution of $2.10 \mathrm{keV}$ at $1332 \mathrm{keV}$. The concentration of the analyzed elements was determined by comparing activities obtained in the samples with standard reference materials IAEA SL-1 lake sediment and IAEA SL-3 lake sediment. The spectra analyses were made by WinnerGamma program on InterWinner (InterWinner, 2004). The concentration of the metals was obtained by comparing irradiated standard and sample peak areas in the gamma-spectra by the expression: 


$$
C_{a}^{i}=\frac{\left(A_{a}^{i} \cdot m_{p} \cdot C_{p}^{i}\right) \cdot e^{\lambda(t a-t p)}}{A_{p}^{i} \cdot m_{a}}
$$

where: $\mathrm{C}_{\mathrm{a}}{ }^{\mathrm{i}}=$ i-element concentration in the sample $(\mu \mathrm{g}$ $\left.\mathrm{g}^{-1}\right)$

$\mathrm{C}_{\mathrm{p}}{ }_{\mathrm{i}}^{\mathrm{i}}=\mathrm{i}$-element concentration in the standard $\left(\mu \mathrm{g} \mathrm{g}{ }^{-1}\right)$

$\mathrm{A}_{\mathrm{a}}{ }^{\mathrm{i}}$. $=\mathrm{i}$-element peak area in the sample (cps)

$\mathrm{A}_{\mathrm{p}}{ }^{\mathrm{i}}=\mathrm{i}$-element peak area in the standard (cps)

$\mathrm{m}_{\mathrm{a}}$ e $\mathrm{m}_{\mathrm{p}}=$ standard and sample weight, respectively $(\mathrm{g})$

$\lambda=$ radioisotope decay constant $\left(\mathrm{t}^{-1}\right)$

$t_{a}-t_{p}=$ Difference between sample and standard count time (min).

The determination of the minimum detectable activity (MDA) for INAA was carried out using standard reference material (Keith et al., 1983):

$$
M D A=\frac{3 \cdot C_{P R} \cdot \sqrt{B g}}{T \cdot C}
$$

where: $\mathrm{MDA}=$ minimum detectable activity $\left(\mu \mathrm{g} \mathrm{g} \mathrm{g}^{-1}\right)$ $\mathrm{C}_{\mathrm{pR}}=$ concentration of the element in the standard reference material $\left(\mu \mathrm{g} \mathrm{g}^{-1}\right)$

$\mathrm{Bg}=$ background count of the element in the sample (counts)

$\mathrm{T}=$ counting time $(\mathrm{s})$

$\mathrm{C}=$ counting in the peak area of the element in the standard reference material (cps)

$3=$ level between the certified value and the definitive value

\section{Results and Discussion}

The results of metals concentration (As, K, Na, Rb, Sb, $\mathrm{Sm}$ and $\mathrm{Zn}$ ) measured in six species of fish are presented in Table 1.

The relative accuracy ranged from $1 \%(\mathrm{Na})$ to $9 \%$ (As) and relative precision from $4.4 \%(\mathrm{Na})$ to $10 \%(\mathrm{Rb})$ for standard reference material IAEA SL-1. For the standard reference material IAEA SL-3, the relative accuracy ranged from $2.2 \%$ (Th) to $9.3 \%$ (As) and relative precision from $5.9 \%(\mathrm{Na})$ to $11 \%(\mathrm{Rb})$. In general, relative standard deviation and relative error were lower than $10 \%$ proving the precision and accuracy of the INAA technique.

The following elements presented concentration below the MDA: Co $\left(<0.75 \mu \mathrm{g} \mathrm{g}^{-1}\right)$, Cs $\left(<0.51 \mu \mathrm{g} \mathrm{g}^{-1}\right)$, Fe $\left(<0.06 \mu \mathrm{g} \mathrm{g}^{-1}\right)$, Sc $\left(<0.1 \mu \mathrm{g} \mathrm{g}^{-1}\right)$, Th $\left(<0.35 \mu \mathrm{g} \mathrm{g}^{-1}\right)$ and $U\left(<0.54 \mu \mathrm{g} \mathrm{g}^{-1}\right)$.

According to Codex (2010), As can be present in marine fish in concentration up to $50 \mathrm{mg} \mathrm{kg}^{-1}$ on a wet weight, in organic form.

The limit adopted by the Brazilian Regulatory Agency (ANVISA, 1998) is $1 \mathrm{mg} \mathrm{kg}^{-1}$ on a wet weight for As, in the inorganic form. The result of As concentration obtained in seawater fishes on a dry weight are above the maximum limit adopted by ANVISA. Borak and Hosgoog (2007) stated that most of the As concentration values in marine fish in the organic form is not toxic to human. It is interesting to note that the As concentrations obtained in the marine fish are higher than those for the river fishes.

Higher concentration values were also observed for $\mathrm{Zn}$, but the results obtained are below the maximum limit adopted by ANVISA for Zn (50 $\left.\mathrm{mg} \mathrm{kg}^{-1}\right)$.

$\mathrm{Rb}$ presented higher concentrations in brycon and pacu, which are river fishes. However, no limits are established for this elements in the Brazilian Regulatory Agency.

The concentrations obtained in this work are in good agreement with values reported in literature (Souza et al., 2009; Kuniyoshi et al., 2011).

\section{Conclusion}

Most of the results obtained for the metals concentration is low or below the detection limits of INAA, exception for As in brycon $\left(5.2 \pm 0.3 \mu \mathrm{g} \mathrm{g}^{-1}\right)$, in catfish $(29.0 \pm 1.6$ $\left.\mu \mathrm{g} \mathrm{g}^{-1}\right)$, in hake $\left(4.3 \pm 0.2 \mu \mathrm{g} \mathrm{g}^{-1}\right)$ and in sardine $(5.8 \pm$ $\left.0.4 \mu \mathrm{g} \mathrm{g}^{-1}\right)$. Rb presented higher concentration in brycon $\left(17.7 \pm 1.1 \mu \mathrm{g} \mathrm{g}^{-1}\right)$ and in pacu $\left(25.2 \pm 1.6 \mu \mathrm{g} \mathrm{g}^{-1}\right)$. Zn presented higher concentration in anchovy $(17.0 \pm 1.0 \mu \mathrm{g}$ $\left.\mathrm{g}^{-1}\right)$, in catfish $(32.9 \pm 1.6 \mu \mathrm{g}$

Table 1. Results of the metals concentration $\left(\mu \mathrm{g} \mathrm{g}^{-1}\right.$ on a dry weight) in the six species of fish.

\begin{tabular}{ccccccc} 
Element & anchovy $^{(\mathrm{a})}$ & brycon $^{(\mathrm{b})}$ & catfish $^{(\mathrm{a})}$ & hake $^{(\mathrm{a})}$ & pacu $^{(\mathrm{b})}$ & sardine $^{(\mathrm{a})}$ \\
\hline $\mathrm{As}$ & $5.2 \pm 0.3$ & $<0.42$ & $29.0 \pm 1.6$ & $4.3 \pm 0.2$ & $<0.42$ & $5.8 \pm 0.4$ \\
$\mathrm{~K}$ & $0.86 \pm 0.18$ & $1,0 \pm 0.2$ & $1.7 \pm 0.3$ & $1,9 \pm 0.4$ & $1.0 \pm 0.2$ & $0.6 \pm 0.1$ \\
$\mathrm{Na}$ & $0.16 \pm 0.01$ & $0.14 \pm 0.01$ & $0.27 \pm 0.01$ & $0.42 \pm 0.01$ & $0.19 \pm 0.01$ & $0.18 \pm 0.01$ \\
$\mathrm{Rb}$ & $<5.9$ & $17.7 \pm 1.1$ & $<5.9$ & $<5.9$ & $25.2 \pm 1.6$ & $<5.9$ \\
$\mathrm{Sb}$ & $0.84 \pm 0.09$ & $<0.22$ & $3.55 \pm 0.36$ & $<0.22$ & $<0.22$ & $1.78 \pm 0.19$ \\
$\mathrm{Sm}$ & $0.04 \pm 0.01$ & $<0.02$ & $0.03 \pm 0.01$ & $<0.02$ & $<0.02$ & $<0.02$ \\
$\mathrm{Zn}$ & $17.0 \pm 1.0$ & $8.1 \pm 0.8$ & $32.9 \pm 1.6$ & $17.5 \pm 1.1$ & $11.7 \pm 0.9$ & $30.0 \pm 1.5$ \\
\hline
\end{tabular}

(a) seawater fish.

(b) river fish. 
$\left.\mathrm{g}^{-1}\right)$, in hake $\left(17.5 \pm 1.1 \mu \mathrm{g} \mathrm{g}^{-1}\right)$ and in sardine $(30.0 \pm 1.6$ $\left.\mu \mathrm{g} \mathrm{g}^{-1}\right)$.

$\mathrm{Rb}$ showed the highest concentrations in the river fishes; and the elements As and $\mathrm{Zn}$ in seawater fishes.

The results obtained in this study can be used to ensure the quality of the fish consumed in the city of São Paulo.

\section{References}

ANVISA - Agência Nacional de Vigilância Sanitária, Ministério da Saúde; Portaria no 68 de 27/8/1998.

Borak J, Hosgood HD. Seafood arsenic: implications for human risk assessment. Regulatory Toxicology and Pharmacology; 2007; 47:204-212.

Codex. CODEX GENERAL STANDARD FOR CONTAMINANTS AND TOXINS IN FOOD AND FEED. Codex Standard 193-1995 Adopted 1995; Revised 1997, 2006, 2008, 2009; Amended 2009, 2010.

Fabiano KC, Moreira EG, Vasconcellos MBA, Lima APS. Determinação de elementos essenciais e tóxicos em corvina (micropogonias furnieri) consumida na cidade de São Paulo por análise por ativação com nêutrons. International Nuclear Atlantic Conference, 2011; ISBN: 978-85-99141-04-5.

Governo do Estado de São Paulo - Secretaria dos
Serviços e Obras Públicas. Água - qualidade, padrões de potabilidade e poluição. São Paulo, Brazil; Cetesb; 1974.

InterWinne. InterWinner ${ }^{\mathrm{TM}}$ 6.0 MCA Emulation, Data Acquisition and Analysis Software for Gamma and Alpha Spectroscopy IW-B32. ORTEC, Oak Ridge, TN, USA. 2004.

Keith LH, Crummet,W, Deegar JP, Libby RA, Taylor JK, Wenter, G. Principles of environmental analysis. Anal. Chemistry 1983; 55:2210-2218.

Kunioshi LS, Braga ES, Favaro DIT. Uso doarsênio na avaliação da qualidade do pescado:necessidade de adequação da legislação ambiental. V Simpósio Brasileiro de Oceanografia, 2011.

Nascimento SM, Farias LA, Curcho MRM, Braga ES, Fávaro DIT. Estudo comparativo de constituintes nutricionais e do teor de mercúrio total em peixes comercializados na cidade de Cananeia, litoral de São Paulo. International Nuclear Atlantic Conference - 2009.

Souza GR, Garcez MAP, Santos VCG, Silva DB, Caetano J, Dragunski DC. Quantificação de metais pesados em peixes de um pesqueiro localizado na cidade de Umuarama - Pr. Arq. Ciênc. Vet. Zool. Unipar, 2009; 12:61-66. 